\title{
Microbiological analysis on bone flour patin fish (Pangasius Hypophthalmus Sp.) biscuit is rich in calcium for children
}

\author{
Dewi Sartika Siagian ${ }^{1 *}$, Wahyu Margi Sidoretno², Sri Kartini ${ }^{3}$ \\ ${ }^{1}$ Program Studi Kebidanan Universitas Abdurrab, Jl. Riau Ujung no. 73 Pekanbaru, postcode 28291, Indonesia \\ ${ }^{2,3}$ Program Studi D-III Analis Farmasi dan Makanan Universitas Abdurrab, Jl. Riau Ujung no. 73 Pekanbaru, \\ postcode 28291, Indonesia \\ ${ }^{1}$ dewi.sartika.siagian@univrab.ac.id*,2wahyu.margi@univrab.ac.id, ${ }^{3}$ sri.kartini@univrab.ac.id \\ *corresponding author
}

Submission date: 16 April 2021, Receipt date: 3 Mei 2021, Publication date: 1 Juli 2021

\begin{abstract}
Ikan Patin bones are a by-product of the fish processing industry which contains the most calcium from the fish body because the main elements of fish bones are calcium, phosphorus and carbonate. Biscuits are snack that have a water quality standard of less than 5\% so that they have a crunchy texture. The purpose of this study was to see microbial contamination in biscuits using the ALT (Total Plate Number) method. The type of research carried out is experimental research. The results of microbial contamination meet the specified requirements and are included in the category of safe and normal standards according to SNI 2973:2011. The results of the identification of Coliform and E. coli bacteria, can be seen that the biscuits with or without the addition of Patin Fish bone meal contain less than the stipulated provisions.
\end{abstract}

Keywords: patin bones, biscuits, microbial

\section{INTRODUCTION}

Patin fish bones are a by product of the fish processing industry which contains the most calcium from the fish body because the main elements of fish bones are calcium, phosphorus and carbonate (Kordi, 2010). Calcium absorption and retention in body is influenced by the quantity and quality of the dietary protein consumed. The interaction between calcium and protein is of special concern considering the fact that bone tissue is nearly 50 per cent protein by volume and other 50 per cent of bone is calcium (AgraharMurugkar et al. 2018).

One of the easiest and cheapest food sources to obtain is fish, such as Patin fish. Patin fish is a fish that is classified as tasty, delicious and savory fish. In addition, Patin fish contains high protein and low cholesterol. Patin contains $68.6 \%$ protein, $5.8 \%$ fat, $3.5 \%$ ash, and 59.3\% water (Kordi, 2010). Fish bone meal contains high levels of calcium and phosphorus which is high enough so that when used as a fortification materials in food products can be used as a source of calcium and from fish processing by fish bone separator machine. In $100 \mathrm{~g}$ of bone meal fish, contains $735 \mathrm{mg}$ of calcium; 9.2 grams of protein; $44 \mathrm{mg}$ fat; $345 \mathrm{mg}$ phosphorus; $78 \mathrm{mg}$ of iron; 24.5 grams of ash; and other minerals. High content fish bone calcium shows that fish bones has potential as a source 
of calcium that are easily accessible to the public and can be used as alternative diet to prevent disease due to deficiency calcium (Sari 2013).

Patin fish bone meal is rich in nutrients. The nutritional content of Patin fish bone meal can be determined by proximate analysis and mineral analysis. Proximate analysis is the determination of the percentage of the main components (ash content, moisture content, fat content, protein and carbohydrates) of food stuffs, while mineral analysis is the determination of the percentage of calcium and phosphorus in food stuffs. Patin fish bone meal contains $25.6 \%$ calcium and $15.1 \%$ phosphorus.

Biscuits are snacks that have a water quality standard of less than $5 \%$ so they have a crunchy texture (Thompson Coon 2010). The chemical properties of biscuits can be seen from the parameters of moisture content, fat content, protein content, and ash content according to the Indonesian National Standard. Changes in the chemical properties of biscuits can occur due to the influence of several factors, such as the composition of the ingredients, temperature and baking time. The biscuit quality standard as a whole has been regulated in SNI 2973-2011(Indonesia 2011).

Stunting is one of the nutritional problems in Indonesia, the direct causes of stunting are infectious diseases and inadequate food intake, such as protein and calcium deficiency (Nur Afrinis 2018). Biscuits with additional patin fish bone meal are biscuits that contain calcium so that they can be given to children under five to support growth and development. These protein and calcium rich biscuits can help overcome many nutritional deficiencies and can add variety to the bakery industry (Agrahar-Murugkar et al. 2018). The purpose of this study was to see microbial contamination in biscuits and to determine the number of microbes contained in biscuits so that they are safe for consumption. Stunting is one of the nutritional problems in Indonesia In Indonesia, the direct cause of stunting is disease infection and inadequate food intake, such as protein and calcium deficiency (Nur Afrinis 2018).

Based on research (Nur Afrinis 2018) on the formulation and characteristics of bihun high in protein and calcium with the addition of Patin fish bone meal (pangasius hypopthalmus sp.) For stunting toddlers with the aim of knowing the best formula and characteristics of bihun high in protein and calcium with the addition of fish bone meal Patin fish (pangasius hypopthalmus sp.). The results of research on Patin fish bone meal showed protein content of $20.39 \%$, water content of $6.79 \%$, ash content of $64.23 \%$, $3.36 \%$ fat, $8.35 \%$ carbohydrates, $1002.00 \mathrm{mg} / 100 \mathrm{~g}$ calcium, and formulations.

\section{RESEARCH METHODS}

In addition to determining the quality of biscuits using chemical criteria, it is also necessary to determine microbial contamination. This aims to determine the number of microbes contained in biscuits so that they are safe for consumption. The principle is to liberate bacterial cells that may be protected by food particles and to reactivate bacteria which may have reduced viability due to unfavorable conditions in food. Microbial contamination using the ALT method (Total Plate Number) has a maximum limit of $1 \mathrm{x}$ 104 colonies / g.

This research is an experimental research which carried out in the Food and Beverage Analysis laboratory, School of Medicine and Health Sciences Abdurrab 
University, namely by making biscuits with the addition of Patin fish bone meal flour with different doses, then the test was carried out microbiology. Biscuits added with Patin fish bone meal. Addition of Patin fish bone meal to Biscuits is intended to add nutritional value, especially calcium. In this study, the addition of Patin fish bone meal as much as $25 \%$ in F1 and 50\% in F2, while Biscuits without the addition of Patin fish bone meal are F0. Each concentration/formula is made with ingredients that are the same; it's just that at the concentration of F0 added flour 500 grams of flour and without the addition of Patin fish bone meal. In F1, the added flour is 375 grams while the Patin fish bone meal which added is 125 grams. At F2, the wheat flour that while what is added is as much as 250 grams, flours the added Patin fish bone meal is as much as 250 grams. After that, every cookie dough that has been molded and arranged on a baking sheet in the oven at a temperature of $155^{\circ} \mathrm{C}$.

\section{RESULTS AND DISCUSSION}

Based on the test results, all formulas meet the requirements for microbial contamination limits required by SNI 2973: 2011. This can be seen in the table below;

Table 1. Test Results for Microbial Contamination on Biscuits (2020)

\begin{tabular}{llllll}
\hline Sample & \multicolumn{5}{c}{ Parameters of Microbial Contamination Test } \\
\cline { 2 - 6 } & $\begin{array}{l}\text { Total } \\
\text { Number (Koloni/g) }\end{array}$ & $\begin{array}{l}\text { Plate } \\
\text { Coliform } \\
(\text { APM/g) }\end{array}$ & $\begin{array}{l}\text { Escherecia } \\
\text { coli } \\
(\text { APM/g) }\end{array}$ & $\begin{array}{l}\text { Kapang } \\
\text { Khamir } \\
(\text { Koloni/g) }\end{array}$ & and \\
\hline F0 & $29 \times 10^{1}$ & $<20$ & $<3$ & $14 \times 10^{1}$ \\
\hline F1 & $<2,5 \times 10^{2}$ & $<20$ & $<3$ & $<2 \times 10^{2}$ \\
\hline F2 & $<2,5 \times 10^{2}$ & $<20$ & $<3$ & $<2 \times 10^{2}$ \\
\hline
\end{tabular}

Based on the results of the calculation of microbial contamination using the ALT method (Total Plate Number), it can be seen that the highest number is found in F0, this is because the formula that does not contain Patin Fish bone meal has a higher water content than the other formulas. While the number of bacteria in F1 and F2 is low, this is due to the heating factor and low water content. In addition, the roasting process in biscuit processing causes a decrease in moisture content, there by inhibiting microbial growth. The maximum limit for microbial contamination using the ALT method is $1 \mathrm{x} 104$ colonies/g. Based on the research conducted, the results of microbial contamination using the ALT method still meet the stipulated requirements.

The results of the identification of Coliform and E. coli bacteria, can be seen that the biscuits with or without the addition of Patin Fish bone meal contain less than the stipulated provisions. This result is still declared normal according to SNI 2973: 2011. So it can be indicated that the biscuits made are included in the safe standard category. It is known that Coliform and E. coli are members of the Enterobacteriaceae family, enteric bacteria, which are facultative Gram-negative anaerobic bacteria, which are usually found in the intestinal tract of warm-blooded animals including humans, located in the digestive tract especially in the cecum and large intestine (Tenaillon, 2010). E. coli, can interfere with the gastrointestinal tract in children and adults.

The results of the kapang/kamir test showed that the amount of kapang/kamir in biscuits with the addition of Patin fish bone meal or without Patin fish bone meal was 
still below the SNI requirement, namely a maximum of $2 \times 10^{2}$ colonies $/ \mathrm{g}$. Biscuits that have good storage conditions so that they are not contaminated with outside air will avoid kapang/kamir contamination (Yoen Ju Park 2009). In addition, the presence of kapang/kamir and bacteria can be caused by the raw material used which is thought to have been contaminated with microbes before hand. Raw materials, factory environment, microbiological state of equipment and packages, and lack of cleanliness are all possible factors for microorganism contamination (Tenaillon, 2010). When technological processes are less precise, beverage and food production methods will have a significant impact on the type of spoilage microflora (Kregiel 2015).

Make use of waste Patin fish bone which has great potential for used as raw material for rich bone meal of calcium. So that its use can be made in a form of biscuit product that is acceptable to the public. Biscuits fortified with Patin fish bone meal will add nutritional value, especially calcium so that it can give to toddlers to reduce. (Siagian, Sidoretno, and Kartini 2020). Similarly, the research conducted by Hernawati on Biscuit making with the addition of banana peel flour is an effort to utilize banana processing industrial waste which is expected to be consumed by the community. normal bananas do not exceed the provisions of the Indonesian National Standard (SNI) which requires a maximum of 1.0x104 colonies/g bacteria (Hernawati, Aryani, and Shintawati 2018)

\section{CONCLUSION}

Based on the research conducted, the results of microbial contamination using the ALT method still meet the stipulated requirements. The results of the kapang/kamir test showed that the amount of mold / yeast in biscuits with the addition of Patin fish bone meal or without Patin fish bone meal was still below the SNI requirement, namely a maximum of $2 \times 102$ colonies / g.

\section{REFERENCES}

Agrahar-Murugkar, Dipika, Shraddha Dwivedi, Preeti Dixit-Bajpai, and Manoj Kumar. 2018. "Effect of Natural Fortification with Calcium and Protein Rich Ingredients on Texture, Nutritional Quality and Sensory Acceptance of Cookies." Nutrition and Food Science 48(5):807-18. doi: 10.1108/NFS-02-2018-0041.

Hernawati, Any Aryani, and Rita Shintawati. 2018. "Uji Mikrobiologi Biskuit Dengan Penambahan Tepung Kulit Pisang." Life Science 7(2).

Indonesia, Badan Standarisasi Nasional. 2011. Badan Standarisasi Nasional Indonesia. Biskuit. Sni 2973: 2011.

K, M. Ghufra. H. Kord. 2010. Panduan Lengkap Memelihara Ikan Air Tawar Di Kolam Terpal. Lily Publisher.

Kregiel, Dorota. 2015. "Health Safety of Soft Drinks: Contents, Containers, and Microorganisms." BioMed Research International.

Nur Afrinis, Verawati Besti dan Harahap Dewi Anggraini. 2018. "Formulasi Dan Karakteristik Bihun Tinggi Protein Dan Kalsium Dengan Penambahan Tepung 
Tulang Ikan Patin (Pangasius Hypopthalmus Sp.) Untuk Balita Stunting." MKMI 14(2).

Olivier Tenaillon, David Skurnik, Bertrand Picard, Erick Denamur. 2010. "The Population Genetics of Commensal Escherichia Coli." Nat Rev Microbiol 8(3).

Sari. 2013. "Pengaruh Penambahan Tepung Tulang Ikan Lele (Clarias Batrachus) Pada Pembuatan Mie Basah Terhadap Kadar Kalsium, Elastisitas, Dan Daya Terima." Program Studi Gizi Fakultas Ilmu Kesehatan Universitas Muhammadiyah Surakarta.

Siagian, Dewi Sartika, Wahyu Margi Sidoretno, and Sri Kartini. 2020. "Utilization of Patin Bone Flour r (Pangasius Hypopthalmus Sp.) As an Additional Biscuit For Stunting Children." Jurnal Aisyah: Jurnal Ilmu Kesehatan 5(1):199-203.

Thompson Coon, J. 2010. Goodman and Gilman's the Pharmacological Basis of Therapeutics. Vol. 7.

Yoen Ju Park, Jinru Chen. 2009. "Microbial Quality of Soft Drinks Served by the Dispensing Machines in Fast Food Restaurants and Convenience Stores in Griffin, Georgia, and Surrounding Areas." J Food Prot 72(12). 